RUNNING HEAD: Indigenous Deaths in Police Custody

Indigenous deaths associated with police contact in Australia: Event stages and lessons for prevention

Louise E. Porter

ARC Centre of Excellence in Policing \& Security

3.01, Social Sciences Building (M10)

Griffith University

Mt Gravatt Campus

Nathan Qld 4111

Australia

Email: 1.porter@griffith.edu.au

Tel: +61 737351035

Fax: +61 737351033

Louise Porter is a Research Fellow in the Australian Research Council Centre of Excellence in Policing and Security (CEPS) based at Griffith University, Brisbane. Louise is a British Psychological Society Chartered Psychologist and has a Ph.D. and M.Sc. in Psychology from the University of Liverpool UK. Her research interests centre on interpersonal processes, specifically leadership and peer influence in forensic contexts. Louise has explored social and situational features of group crime and, more recently, police corruption and misconduct. 
Indigenous deaths associated with police contact in Australia: Event stages and lessons for prevention

\begin{abstract}
This paper analyses factors involved in Indigenous deaths associated with police contact in Australia since the Royal Commission of Inquiry, with a view to identifying possible points of prevention. Coronial reports were collected of 98 cases of Indigenous deaths, occurring in police custody or during custody-related operations between 1992 and 2008. Cases were content analysed for individual and situational variables, as well as Coroner recommendations. These variables are reported around a framework of the stages of the incident from the initial information or contact through to an officer decision to detain and subsequent aftercare. Subsets are detailed by cause of death. Key issues that affect these stages include the role of alcohol, criminal behaviour and mental health. Suggestions for prevention focus upon alternatives to to the decision to detain in police custody, particularly for minor offences, and improvements in aftercare, particularly regarding police custody procedures.
\end{abstract}

Keywords: Custody death, Police, Indigenous, Prevention, Arrest, Pursuits. 
Indigenous deaths associated with police contact in Australia: Event stages and lessons for prevention

Indigenous deaths in custody are a prominent issue in Australian criminal justice, particularly since the Royal Commission into Aboriginal Deaths in Custody handed down its findings in 1991. The Royal Commission (1991) highlighted the over-representation of Aboriginal people in custody, and the Criminal Justice System in general, compared with non-Aboriginal people. This elevated the impact of numbers of deaths in custody on Aboriginal communities. Further, the Royal Commission identified that Aboriginal people were more likely to have died in police custody than in prisons.

History of over-representation of minorities in the Criminal Justice System is not unique to Australia. Overseas examples include disproportionate arrest rates of AfricanAmericans in the US (e.g. US Department of Justice, 2010), and of Maori's in New Zealand (New Zealand Department of Corrections, 2007). Further, incidents of perceived injustice in Manitoba, Canada, led to the Aboriginal Justice Inquiry (Aboriginal Justice Implementation Commission, 1999); while, in the UK, police have been criticised of being 'institutionally racist' (Macpherson, 1999, para.46.1). The Independent Police Complaints Commission (IPCC, 2011, p.vi) notes that, while every death in custody "represents a tragedy", those of Black and minority ethnic individuals can cause particular public concern.

In Australia, apart from arrests, a picture emerged of significant police system failures; inadequate police training and inadequate awareness of duty of care; as well as a number of factors indicative of wider Indigenous issues concerning culture and disadvantage. Indeed, the over-representation of Indigenous people within sections of the criminal justice system is well documented (see Beresford \& Omaji, 1996; Homel, Lincoln, \& Herd, 1999; Atkinson, 1994). This over-representation, leading to elevated numbers of Indigenous deaths in custody, is influenced by many background factors, including, but not limited to: health, abuse, poor 
living conditions, education, employment, relationships with the police, alcohol and substance abuse.

The present paper analyses Indigenous deaths in police custody (and related operations) in Australia since the 1991 Royal Commission from a situational perspective. The study explores the different stages of these events that led to detention (or attempts to detain), particularly regarding the information available to officers and the decisions they made. By exploring the potential for assessment at each stage, the paper highlights possibilities for preventing future deaths.

\section{In-Custody Deaths}

As a result of the Royal Commission recommendations, the Australian Institute of Criminology (AIC) commenced a "National Deaths in Custody Program" in 1992, which monitors and reports annually on numbers of, and trends in, Australian deaths in prison, police custody and juvenile detention. Based on this work, Joudo and Curnow (2008) reported a further 90 Indigenous deaths in police custody and stated that the number of Indigenous deaths in police custody had been significantly increasing. Further, they reported that the relative proportion of Indigenous to non-Indigenous deaths each year had increased since 2002.

Outside Australia, similar monitoring of in-custody deaths takes place. For example, in the UK the Independent Police Complaints Commission not only reports statistically on deaths in custody but also independently investigates such cases. In the US, the Bureau of Justice Statistics collects data on deaths in custody and deaths during the process of arrest. Deaths in custody can occur as a result of various specific causes, ranging from suicide to homicide, drug overdose to natural causes. Within the Royal Commission, two separate categories were formed: (1) where death occurred by natural causes and (2) where death 
occurred due to external factors. Sixty-three per cent of the Indigenous custody deaths were due to external factors, with almost half of those involving suicide by hanging. Indeed, the majority of the literature on death and injury in custody environments, both nationally and internationally, is focussed on preventing suicide and self harm of prisoners (e.g. Liebling, 1995).

While the interaction of background factors and the pathways to custody, which can then result in deaths in custody, is an important issue, Weber (2007) asserts that "to focus solely on links between socio-economic circumstances and Indigenous criminality would be to misrepresent those problematic interactions between police and Indigenous people" (p.239).

Operations Deaths

The Royal Commission recognised that deaths occur in relation to police contact outside of the direct custodial environment. The interaction of police and citizens, therefore, deserves equal attention, particularly at the operational level prior to (or when) the decision to arrest and detain the person is made. In Australia, in line with the recommendations of the Royal Commission, the definition of a death in police custody, and the focus of the AIC monitoring program, was broadened to include deaths as a result of 'custody-related operations', including where a person is attempting to evade detention or escape custody (McDonald, Howlett \& Dalton, 1992).

Since 1999, police-related deaths (of Indigenous and non-Indigenous people) during operations (e.g. arrests, sieges, police pursuits) have consistently been more prevalent than police custody deaths each year (Joudo \& Curnow, 2008). Petschel \& Gall (2000) profiled all deaths in custody in Victoria from 1991-96 and categorized the causes of death into 'natural', 'accidental', 'suicide', 'homicide' and 'police shootings'. The most frequent of these 
categories was police shootings (18 of the 45 deaths), with a third of these occurring during police pursuits. Indeed, the majority (53\%) of the deaths occurred while being pursued by police, while $29 \%$ occurred in police custody and $18 \%$ while otherwise in police care.

Similarly, Dalton (1998) found that, nationally in Australia, of all 222 deaths 'in police custody' from 1 January 1990 to 30 June 1997, one-third were firearms-related and, of these 75 deaths, more than half were inflicted by police officers. Further, several studies have highlighted an elevated likelihood of police to use force against minorities (e.g. Terrill \& Mastrofski, 2002) and individuals suffering from mental illness (Kesic, Thomas \& Ogloff, 2010; Lawton, 2007).

A stage approach to prevention

Despite the high public profile of the Royal Commission and its recommendations, subsequent controversial deaths of Indigenous people in custody have occurred in Australia. For example, the death of an Indigenous man, Mulrunji, in custody on Palm Island in Queensland in 2004, sparked riots and led to years of subsequent investigation and review. While Leigh, Johnson and Ingram (1998) posit that not all deaths in police custody are avoidable, Pelfrey \& Covington (2007) suggest that the logical converse is that some deaths may be preventable. Indeed, the Coroner's inquest report (Queensland Coroner's Court, 2006) on the death of Mulrunji highlighted a number of stages during which the death might have been prevented. For example, Mulrunji was arrested for 'public nuisance' offences including drunkenness and verbal abuse (rather than being given a caution or summons), the intoxicated Mulrunji was held in a police cell (rather than a medical or community facility); and police failed to properly assess Mulrunji's health while in custody. A stage approach recognises that prevention can occur at a number of points leading up to the 'final frame', rather than focusing on only the most proximal circumstances to the death. 
Police use of force literature offers a useful framework for understanding some of the stages of police-citizen encounters that might lead to death. Binder and Scharf (1980) and Fridell and Binder (1992) offered a four stage model for exploring police decisions to use force in potentially violent encounters. Stage one is an initial stage of anticipation, where officers receive information prior to the direct encounter (for example, over the police radio). This could include details of the incident needing a response, information regarding offending behaviour, and history of the person of interest. Stage two is the initial contact, where the officers can begin to gather information directly, for example by observing the scene and person of interest. Stage three involves information exchange between the officer and the person of interest, usually dialogue but also including non-verbal behaviour. Stage four of their model is the final decision, or final frame, for example where an officer decides to shoot or not shoot a suspect. Each stage involves information gathering and interpretation by the officers that leads to the final decision, and possible difficulties can arise due to information ambiguity, absence, or error, as well as interpretive bias. Fridell and Binder (1992) stated that 'not all potentially violent confrontations include all stages' (p. 387). Further, Binder and Scharf (1980) noted that the options available at the final stage are often influenced or constrained by what has occurred in the previous stages. They, therefore, posit that 'interventions to control deadly force might be effectively aimed at an officer's decision well in advance of the final frame' (Binder \& Scharf, 1980, p. 119). While this work concentrated primarily on the decision of officers to employ lethal force, this paper argues that such a stage model applies to many police-citizen encounters and is a useful framework for exploring information received, and officer decisions, in encounters that led to death, even if that death was unintentional.

The present paper provides the contribution of examining cases of death associated with police operations as well as those that occurred in police custody. The utilisation of 
Coronial reports extends the analyses further through the inclusion of relevant Coroner recommendations. These recommendations are analysed alongside elements of the cases at each stage of the event, to determine how, and at which stages, prevention efforts might best be targeted, and whether this differs by cause of death.

\section{Method}

\section{Sample}

The sample consisted of 98 cases of death that occurred between 1992 and 2008. Just over a third (38\%) occurred between 1992 and 2000 (inclusive), with the remaining 62\% occurring from 2001 to 2008 . The 98 cases represent 91 separate incidents, since three incidents involved multiple deceased persons under circumstances in line with the inclusion definition outlined below. These three incidents were vehicle-related, with the additional people as passengers.

Cases were sought from all eight jurisdictions (States and Territories) of Australia. Data were collected from all jurisdictions with the exception of the Australian Capital Territory (ACT), which had experienced no Indigenous deaths in police custody or associated operations during the time period of interest. The largest number of cases occurred in Western Australia (28) and the Northern Territory (27). Table 1 shows the population figures for each jurisdiction. Northern Territory, while having the smallest total population, has the largest Indigenous proportion of population: 30\% compared with the other jurisdictions where less than $4 \%$ of the population are Indigenous. This might account for the high number of cases from the Northern Territory.

\section{[Insert Table 1 here]}

Data Collection 
Coroner reports were collected of closed cases of people identified as Indigenous whose death was associated with police custody, and occurred since the Royal Commission in 1991. The study adopted an extended definition of "custody" where a death in police custody is taken as when: a person who has died was either in police custody, escaping from police custody or trying to avoid police custody. Further, those cases that were investigated as possible deaths in custody were also included; for example, where the deceased were passengers in a vehicle driven by a person who police sought to apprehend but where police were not necessarily seeking directly to apprehend the passengers. It was the view of some Coroners, and of the researchers, that they are still deaths associated with police contact and the fact that they do not reach the formal definition for reporting purposes means that these cases go unanalysed by other research. The purpose here was to be as inclusive as possible to maximise the learning for prevention.

All deaths in custody in Australia are subject to a Coronial investigation. Since 2000 (2001 in Queensland), the materials and findings of these investigations are stored in an electronic database in the National Coroner's Information System (NCIS). Cases before these dates are held at the relevant State and Territory Coroner's office. Sixty cases were collected through the NCIS, with the remaining 38 collected directly from Coroners' offices. The AIC monitoring program provided information and liaised with Coroners to aid the location of relevant files. Based on AIC information, 96 cases were sought. Sixteen of these were not able to be collected ${ }^{1}-$ seven from post-NCIS, nine from pre-NCIS. This may be due to cases still being open or older files unable to be located in archives. A further 19 cases were collected beyond those specifically sought: two supplied by Coroners and 17 found through the NCIS system, due to the searchable nature of the database and this study's expanded definition for cases of interest. The actual number of cases collected is, therefore, different to the number sought, so figures for both are provided in figure 1. 
[Insert fig.1 here]

Coroner reports are a rich source of data for prevention-oriented research. Pelfrey and Covington, (2007), in the US, particularly advocated the use of Coroners for research to "advance the understanding of the situational exigencies (Bittner, 1970) surrounding deaths that occur while in police custody" (p.68). They argued that Coroners provide a more efficient and valid source of information for this topic than law enforcement agencies, particularly since they represent a neutral component of the criminal justice system. Further, Pelfrey \& Covington, (2007) argued that Coroners provide a new source of information that had not been used previously for exploring deaths in police custody that also eliminates sampling error since the entire population can be specified and collected in the research.

Dalton (1998) emphasises how Coroners normally examine the role of the police in a death in custody in every detail and may highlight inadequacies in investigations by police. According to Dalton, the role of the Coroner is to identify the deceased; determine the date and place of death; determine the manner and cause of death (including the circumstances surrounding the death); and, if applicable, make recommendations to the appropriate authorities to prevent a death in similar circumstances occurring in the future.

Data Coding and Analysis

The 98 cases were content analysed using a coding dictionary developed from a pilot content analysis of a sample of reports and factors identified by the Royal Commission. The coding dictionary set out features of the cases as variables (each with a specific definition). Each case was then coded against those variables to form a database. Features, or variables, covered officer/victim characteristics (for example, age, gender) and situational factors (e.g. where events took place) and specific events leading to the deaths (e.g. cause of death, circumstances of death). An important step in the development of a coding dictionary is to 
assess the reliability of the variable descriptions through inter-rater agreement. Ten cases ( $10 \%$ of the sample) were coded by a second researcher in order to assess inter-rater agreement. Discrepancies were discussed between the researchers and the coding scheme refined until variables were shown to be unambiguous and reliable across different coders.

The unit of analysis was the deceased person (and the circumstances leading to that person's death). Variables were analysed with reference to the stages of the Binder and Scharf (1980) model. The inclusion of in-custody deaths in the current paper, however, necessitates the addition of a fifth stage that focuses on aftercare. Thus, the stages, as outlined in Table 2 were: anticipation, initial contact, information exchange, final decision, and, aftercare. The results are discussed in subsamples according to the cause of death.

[Insert table 2 here]

Results

Sample: Deceased Persons

The sample contained 98 deceased persons, 80 Males and 18 females. A summary of demographic and background characteristics is provided in table 3. The person's age was available for 88 cases and ranged between 12 and 58 years old (Mean age 29 years; SD = 11). Eighteen per cent were under 18 years old at the time of death and approximately $20 \%$ were aged 40 or over.

[Insert table 3 here]

Those with a history of drug/alcohol abuse tended to be older (mean age 35.5) than those who did not (mean age 25.1) $(\mathrm{t}=-4.8, \mathrm{df}=86, \mathrm{p}<.001)$. Drug/alcohol abuse was also positively linked to having a criminal history $\left(\chi^{2}=14.4, \mathrm{df}=1, \mathrm{p}<.001\right)$, although having a criminal history did not itself show a relationship with age $(\mathrm{t}=-1.06, \mathrm{df}=86, \mathrm{p}=.113)$. Those 
with a history of health problems tended to be older (mean age $=40.25$ ) than those who did not $($ mean age $=25.96)(\mathrm{t}=-5.95, \mathrm{df}=86, \mathrm{p}<.001)$. Health problems and history of drug/alcohol abuse were positively related $\left(\chi^{2}=13.8, \mathrm{df}=1, \mathrm{p}<.001\right)$.

\section{Subsamples: Cause of Death}

The cause of death was identified by Coroners in 96 cases, with the majority of these attributed to external (79) rather than internal (17), causes. The nature of the injury that directly caused the death, and how it was caused, is recorded by the Coroner in most cases, although in some cases this information was missing ${ }^{2}$. Table 4 shows that the predominant internal cause $(71 \%)$ was related to heart failure/heart disease. External causes of death were by a vehicle (40\%), suicide (18\%), police (8\%), an accident $(7 \%)$ or another person (one case). Figure two shows that, across the subtypes of cause of death, WA and $\mathrm{NT}^{3}$ have had a much higher incidence of vehicle-related deaths.

\section{[Insert Table 4 here]}

[Insert Fig 2 here]

Subsamples according to the predominant ${ }^{4}$ causes of death are compared below first in relation to the personal characteristics of the deceased, and then the situational characteristics of the event and Coronial recommendations relevant to the stage framework outlined previously.

\section{Personal Characteristics of Subsamples}

Table 3 provides demographic details of the subsamples. The majority of cases in all categories were of deceased males. However, females were slightly over-represented in 
vehicle-related deaths, constituting $26 \%$ (10 cases), and slightly under-represented in cases of police-inflicted death. Accidental deaths were all of males. With an average age of 40 years old $(\mathrm{SD}=10$ years $)$, sufferers of internal causes were significantly older than those who died from external causes $($ mean age $=27$ years; $\mathrm{SD}=10 \mathrm{yrs})(\mathrm{t}=4.6, \mathrm{df}=84, \mathrm{p}<.001)$. An internal cause of death was also significantly related to the existence of prior health problems $\left(\chi^{2}=31, \mathrm{df}=1, \mathrm{p}<.001\right.$, Fisher's exact test $\left.\mathrm{p}<.001\right)$ and a history of drug and/or alcohol abuse $\left(\chi^{2}=7.1, \mathrm{df}=1, \mathrm{p}<.01\right)$. Indeed, $76 \%$ of those suffering an internal cause of death were under the influence of alcohol at the time of the event that led to their death.

Vehicle-related deaths involved deceased persons of a younger average age (23 years) than the other categories of death. While only five had a history of drug or alcohol abuse, the deceased was under the influence of alcohol at the time of the death in 24 cases (62\%), and had consumed drugs of some kind at the time in 14 cases $(36 \%)$.

Those who died of police-inflicted injuries showed a higher incidence of criminal history than the whole sample, but much lower likelihood of drug use at the time of the incident. In contrast, accidental deaths showed the opposite relationship, with lower likelihood of criminal history but a high proportion under the influence of drugs at the time. Suicides showed high incidence of criminal history, drug/alcohol history and a high likelihood of being under the influence of drugs at the time of the incident. A large proportion ( $72 \% ; 13$ cases) of suicides involved a history of mental health problems, with $44 \%$ having a history of self-harm thoughts, attempts or threats.

Situational Characteristics of the Subsamples and Associated Coroner Recommendations

Internal cause of death 
Anticipation. Table 5 shows the reason for initial police contact with the deceased. The contact between the deceased and the police stemmed from a call for service in almost half of the 17 incidents with an internal cause of death. Calls for service most often reported criminal behaviour but in three cases reported behaviour of the deceased related to alcohol intoxication in the absence of any other criminal behaviour.

[Insert Table 5 here]

Initial contact through to final decision. In the remaining nine 'internal' cases, the police approached the deceased in the course of their routine patrol. Overall, almost half the deceased in these cases were detained for a minor matter such as drunkenness and/or disorderly behaviour (Table 6). Only seven of the 17 cases of internal cause of death involved an initial intention of police to take the deceased into custody. Other intentions were to help the deceased and to seek information/investigate the matter. Thus, for these cases, information gained through contact with the deceased resulted in the decision to detain.

[Insert Table 7 here]

Aftercare. Table 7 shows that the majority of internal causes of death occurred during police custody (in the watch house or in transit to the watch house), rather than during operations to detain the person. In $65 \%$ of cases, the deceased entered police custody in an institution (watch house): for protective custody (6 cases) or for charges brought against the deceased ( 5 cases). All but one experienced their fatal condition at the watchhouse, leading to death in the police cell or in hospital; one died 10 hours after release from custody. 
Of those admitted to the watch house, two cases showed evidence that the police did not sufficiently follow admissions procedures, such as, not allowing the deceased to fully answer admissions questions (regarding current and previous health, etc.) or rushed processing due to understaffing. However, all 11 cases involved an admissions procedure for the deceased to the cells that incorporated some form of information gathering. Indeed, in eight of the 11 watch house cases there was some evidence that the police were aware of the deceased's prior health problems. However, eight of the 11 were under the influence of alcohol and/or drugs at the time, which might have masked the seriousness of the deceased's condition.

While in custody, all but one of the deceased persons was checked by staff at least once (one individual collapsed during the admissions procedure). Eight were checked regularly, most frequently just visually ( 8 cases), but also verbally (3 cases) and physically (3 cases).

Coroner recommendations. Coroners were more likely to make recommendations in cases of internal cause of death than in any of the other categories. Recommendations for external agencies typically focussed on how they could offer support to police or alternative places to divert people away from police cells. For example, provision of suitable alternatives to placing people affected by alcohol in the cells. This would offer police an alternative at the 'final decision' stage.

Most of the recommendations, however, focused on the aftercare stage. For example, many focussed on maximising information gathering during admissions procedures into the police watch house; particularly, improvements to systems for gathering information from those admitted to the cells, including training officers to improve questioning; gathering more information, and also; the use of software for registering and retaining admissions information. The potential use of welfare officers for admissions, and full-time nursing staff 
on hand at admissions, was recommended to remove the onus on police in determining whether an admitted person is intoxicated or suffering a medical condition.

Coroners also made recommendations regarding monitoring of detainees in cells, including adequate watch house staffing, CCTV for monitoring and recording activity, and alarms. Recommendations were made for enhancing police officer capabilities to respond to medical emergencies.

\section{Vehicle-related deaths}

Anticipation. Vehicle-related incidents comprised $49 \%$ of all deaths due to external causes. The reason for the initial contact between the police and the deceased, where known, was due to a call for service in only six cases (15\%), with the remaining contacts being police-initiated (Table 5). Calls for service reported criminal behaviour.

Initial Contact through to final decision. Where police initiated the contact this was most often due to suspicious or criminal behaviour but a fifth were only contacted due to routine patrol including a Random Breath Testing operation. In all, those who died from vehicle-related injuries were most likely (62\%) to have committed only minor offences, such as drunk and/or disorderly behaviour or driving offences. Time of day was known for 27 cases, with $89 \%$ of those occurring at night between $6 \mathrm{pm}$ and $6 \mathrm{am}$.

Table 7 shows that the majority of vehicle-related deaths occurred during custodyrelated operations. Operations-related deaths involved attempts to evade the police, most commonly (92\%) involving a vehicle pursuit that ended with a vehicle crash, where the deceased was either a passenger $(\mathrm{N}=24 ; 71 \%)$ or the driver $(n=10 ; 29 \%)$. Deceased females were always passengers rather than drivers of the crashed car.

Police called off the pursuit in a third of cases (13 cases). This was most often due to safety reasons $(n=7)$ or because they lost sight $(n=4)$ of the deceased. In only four cases did 
the Coronial report specifically find that the officers did not follow pursuit procedure. Procedural failings included the use of inappropriate vehicles; failure to adequately carry out the decision to terminate the pursuit; police joining a pursuit without direction to do so; lack of a valid reason to pursue; police in pursuit while a civilian is in the car; and the police officer not being a qualified pursuit driver (although in the latter case the Coroner ruled that the driving undertaken did not necessitate special training).

Aftercare. The three 'in-custody' deaths related to two accidents after release from custody, and one death in a police cell from injuries sustained prior to police intervention.

Coroner recommendations. Given that the majority of vehicle cases were pursuitrelated incidents, the majority of recommendations were aimed at improving pursuits once that decision had been made; specifically, ensuring officers receive pursuit training, including regular mock pursuit training and advanced training. In support of pursuit decision-making, it was recommended that manuals for pursuits be context appropriate and unambiguous, and communication systems be upgraded to allow for automatic recording of pursuit communications and improve the relay of information during pursuits.

In the cases where the deceased was struck by a car on release from custody, Coroners recommended improving follow-up care. This included suggested discretion to detain a person for longer periods if necessary due to prolonged intoxication, or provision of alternatives to police custody. In one case there was also the question of providing a duty of care post-custody to help the detainee return home safely.

\section{Suicides}

Anticipation. In ten of the 18 suicide cases, the deceased came into contact with police as a result of a call for service (Table 5). Of these, two-thirds (6 cases) involved violence, including domestic violence. 
Initial contact through to final decision. Police-initiated contact was most often due to suspected criminal, violent, or disorderly behavior. In all, the contact with police arose from minor behavior of the deceased in just three cases, with the remaining showing more serious behavior such as theft-related (19\%), harmful behavior towards themselves (25\%) or violence towards others $(38 \%)$.

A high proportion of suicides occurred during an attempt to detain the deceased (39\%), thus during a custody-related operation (Table 7). In all but one of these cases, the deceased committed suicide at a place of residence, and four involved a siege incident.

Aftercare. Exactly half of the suicides occurred while the deceased was in police care (in the police watch house or during police transportation). All but one of these deaths occurred due to hanging; in one case the deceased suffered from an overdose from a substance consumed before police contact. Two cases occurred post-release from custody; one after release, and one after the deceased escaped custody.

In five cases (28\%), the police were found not to have followed correct policy or procedure. Four of these involved suicides while in the custody of police and predominantly highlighted inadequate checks of the deceased's history or failure to adequately understand suicide risk; not removing property that could be used as a ligature; holding the deceased in an unsuitable environment, and; failures to adequately monitor the deceased while in custody. The remaining case involved a siege incident but the failures identified were not found to have contributed to the outcome of the incident.

Coroner recommendations. The majority of recommendations concerned the aftercare stage. External agencies were recommended to improve or review protocols and services, including making staff available to aid police in tasks such as risk assessment. Recommendations for the police included suggestions for policy and operating procedures, including policy that officers make particular inquiries of detainees, and increase 
interdepartmental communication of warnings in detainees' history that suggest risk of suicide. Cell safety was also the subject of recommendations, including the need to install CCTV in cells and to audit cell safety features. In one case the Coroner recommended building new facilities, and in another stated that if detainees are housed in 'substandard cells', support should be provided to allow constant supervision.

\section{Police-inflicted deaths}

Anticipation. In seven of the eight cases where police were listed as causing the death, the reason for the initial contact between the deceased and police was a call for service (Table 5). The remaining case involved the police observing violent behaviour of the deceased. Four of the calls reported that the deceased was armed.

Initial contact through to final decision. In six of the eight cases (75\%) the deceased was armed when the police made initial contact. In all cases there was visual contact between the police and the deceased at the time of the initial encounter, and in all but one there was also verbal contact. In no cases was there physical contact in the initial encounter.

All eight deaths occurred during a custody-related operation (Table 7). In seven of the eight cases, the fatal injury was inflicted during an attempt to detain the deceased. In three of these cases, the incident involved a siege.

Coroner recommendations. Recommendations primarily concerned improvements to police training, and to the response to high risk situations, including the prospect of a specialised response unit. Indeed, two of the cases highlighted behaviour of officers that was not in line with training that was likely the result of panic in a rapidly unfolding, dangerous and unfamiliar situation. Thus, recommendations targeted the stages associated with assessing the risk of the situation appropriately and having officers specifically trained to respond and make appropriate decisions. 
Accidental deaths (non-vehicle related)

Anticipation. The seven cases that resulted in accidental death began with police contact due to a call for service in four cases (57\%) (Table 5). Calls for service concerned varied incidents, including 'strange behaviour' of the deceased, property-related offences with violence, and public disorder.

Initial Contact through to final decision. In the two cases where police initiated the contact, one was driving erratically while one was not of interest to police (who were undertaking operations to apprehend a different person). Five of the accidents occurred in association with a custody-related operation (Table 7). Thus, police decided to attempt to detain, in most cases, and the deceased fled or resisted. Injuries incurred were mainly due to falls.

Aftercare. Two accidental deaths occurred in custody. One occurred during transportation, due to the deceased not being secure in the police van. A further case involved acute alcohol toxicity in a police cell. In both cases the Coroner commented that the police failed to follow policy, referring to a failure in duty of care, particularly regarding satisfactory welfare checks.

Coroner recommendations. Recommendations to police concerned improvements to prisoner transportation vehicles, amendments to the use of force manual, improving communication of information during police operations, and improving duty of care to detainees.

\section{Discussion}

The 98 deaths fell predominantly within five categories of cause of death: internal cause of death, and external deaths caused by a vehicle, suicide, police or an accident. Over 
$80 \%$ of the deaths were due to external factors, which is a larger proportion than was seen in the Royal Commission where two thirds of the Indigenous custody deaths were due to external factors. Further, with the widened definition of a death in custody, $65 \%$ of deaths occurred during custody-related operations, rather than actually in police custody. While differences across the categories of deaths reported here were found, there are issues common to many of the cases that affected the information received and processed by officers during the anticipation stage, or experienced during the initial contact and information exchange. These include alcohol and drug use, criminal behaviour and mental health issues, which will be discussed in detail before turning to possible avenues for prevention of deaths.

\section{The Role of Alcohol and Drugs}

Alcohol was a factor in the majority of the sample cases. Cases were linked to alcohol through the deceased having a history of alcohol abuse; being intoxicated; being arrested for offences related to intoxication; and alcohol being the cause, or linked to the cause, of death. The frequent appearance of alcohol-related issues in the present sample of cases of deaths of Indigenous people mirrors cases of deaths in custody in other countries, for example in the UK (IPCC, 2011) and Canada (Giles and Sandrin1992). In the present study, the deceased was particularly likely to have been drinking in cases of death due to internal causes and also vehicle-related deaths. Drug use featured in the present sample cases to a lesser extent than did alcohol, but was more frequent in cases of suicide and accidental death.

Long-term alcohol use can cause or exacerbate both mental and physical health problems. The IPCC (2011) in the UK noted that the most common cause of death where alcohol was a factor was natural causes, around a third of which were related to alcohol use. In the present sample, three quarters of those suffering an internal cause of death had consumed alcohol at the time of the death, nearly $20 \%$ higher than the incidence in the whole 
sample. These individuals, as well as being, on average, the oldest subsample of deceased persons, also exhibited three times the incidence of prior health problems than the whole sample, and double the incidence of drug/alcohol abuse history. Giles and Sandrin (1992) reported cases of death due to acute intoxication. Cases of simple alcohol poisoning were seen in the present sample of Indigenous deaths, although they were rare.

Intoxication can increase the chances of receiving injuries, for example through falls, or other accidents (vehicle and non-vehicle related). Intoxication can mask physical symptoms, including symptoms of head injuries, meaning that health assessments on admittance to custody are difficult, or in some cases merely overlooked (IPCC, 2011). This issue was highlighted by the Royal Commission (1991) and also by Giles and Sandrin (1992).

The Role of Mental Health Issues

Almost one fifth of the deaths were ruled as suicides by the Coroner. The Australian Bureau of Statistics (2010) shows that suicide is the sixth leading cause of Indigenous deaths. Suicides occurred in custody, post-custody, and during custody-related operations, with the deceased exhibiting a high incidence of drug/alcohol abuse history, criminal history and mental health problems. Further, these individuals showed almost double the incidence of drug use at the time of the event, as compared to the incidence for the whole sample.

A study into suicide among Aboriginal communities of Queensland (Hunter, Reser, Baird \& Reser, 2001) highlighted hanging as the most common method of suicide and discussed hanging as culturally and symbolically significant for Indigenous people, as well as the method often most accessible. Whilst hanging accounted for over half of the cases, a significant proportion involved more violent means, including gunshot and the use of knives. In some cases police were called to assist where the person was in the process of selfharming, by which stage prevention of death was very unlikely. In other cases, police were in 
a position to assess and identify suicide risk but procedures to decrease the risk (e.g. removal of potential means for suicide) failed, or were not performed.

The Role of Criminal Behaviour and Calls For Service

Alcohol abuse and intoxication can be linked to offences and behaviour that attracts the attention of police. Many of the cases involved a call for service and/or assistance from members of the public regarding the deceased's behaviour, including reporting criminal activity, such as theft and burglary, and/or dangerous behaviour such as assault, domestic violence, public fighting, and carrying of weapons including firearms and knives.

However, similar to reports by the IPCC (2011) on deaths in the UK, and the Royal Commission (1991), a large proportion of the cases involved only minor offences such as drunkenness, public disturbance and driving offences. Arrest, or attempts to arrest, for these offences then resulted in vehicle pursuit deaths, accidents, and deaths due to natural causes. Potentially, if alternative courses of action had been taken, such deaths may have been prevented.

\section{Prevention}

As noted in the introduction to this paper, many deaths in custody have been highlighted in hindsight as possibly preventable. As Norfolk (1998) noted, in many of the UK deaths in custody cases "alternative management could have led to a more favourable outcome. However, this in no way implies fault on behalf of either the police or doctors involved" (p.51). Many efforts have been made to highlight possibilities for preventing deaths in custody. Some suggested initiatives are discussed here in respect of the stages of the final decision to detain and also aftercare, in light of the issues raised above. 


\section{Final Decision: Custody Alternatives}

Given the low level of offences in which many of the deceased persons were involved, there are arguments for whether detention in custody was necessary, or whether police custody was the most appropriate place for detention. With regard to the former, rather than arrest, alternatives such as a caution or summons could have been used. However, the Coroner was in agreement with the decision to detain the deceased in the majority of cases.

In cases where arrest is resisted or evaded, a further risk assessment decision needs to be made as to the appropriateness of pursuing the detention attempt. Indeed, a large number of the deaths in this study were from vehicle pursuits, particularly in Western Australia and the Northern Territory. Australia's Queensland Police Service (QPS) has implemented a restrictive pursuit policy supported by legislative changes to the Police Powers and Responsibilities Act 2000 known as the 'evade police provisions'. The new policy and legislation restricts when pursuits are permitted but provides powers to aid later detection and arrest of drivers. In the current sample, a restrictive pursuit policy may have prevented deaths, but 'evade police provisions' are only effective where the driver is identifiable, rather than, for example, vehicle theft.

There are questions in some cases as to whether police custody, as opposed to some other 'custodial' or care facility, was the most appropriate environment in which to hold the deceased. For example, many authors have highlighted that alternative environments to police custody should be offered to those arrested for drunkenness and related minor offences who are detained for their own protection (Royal Commission, 1991; Blaauw, Kerkhof, and Vermunt, 1997; IPCC, 2011). Particularly, Blaauw, et al. (1997) highlight that such individuals do not pose a serious threat to the public.

In the UK, Guidance on the Safer Detention \& Handling of Persons in Police Custody produced on behalf of the Association of Chief Police Officers (ACPO, 2006) states that "a 
person found to be drunk and incapable should be treated as being in need of medical assistance" (p. 128). Scotland has seen important advances in partnerships between the Police Service and Ambulance Service, including development of a Memorandum of Understanding for the management of drunk and incapable people, providing a framework with agreed responsibilities and referral flow chart (ACPOS, 2011). However, the MoU relies on the provision of suitable alternative services. In the current study, despite introduction of sobering-up shelters in Australia since the Royal Commission, some cases still identified a lack of alternative services, where sobering up shelters required additional funding to function adequately, with limits on capacity or opening hours. A recent review in Scotland (Scottish Government Social Research, 2009) reported that stakeholders and service users supported the proposal that funding for shelters should be provided by 'the drinks industry' (p.65).

In some cases, a hospital setting may be more appropriate, particularly if the person is injured, suffering acute intoxication, or exhibiting other risk factors. For example, Blaauw, et al. (1997) and Norfolk (1998) note that those at high risk of suicide should be taken to a hospital setting rather than police stations. Karch \& Stephens (1999) acknowledge, though, that ambulance staff may not accept violent patients. Sobering-up shelters may also refuse admittance due to violent behaviour, which occurred in the current sample.

\section{Aftercare: Police custody improvements}

Clearly there are many instances where detention in police custody is necessary, due to the nature of offences committed, or lack of alternative services. Under such circumstances there are a number of procedures that have been, or may be, recommended regarding police duty of care towards detainees, particularly in the areas of information gathering and 
management, and assessment. The primary focus of this has been admissions procedures and monitoring of detainees during the custody period.

Admissions/assessment. Detainees in police custody undergo an admissions procedure. Typically, in the cases reviewed in the current study, this involved some form of information gathering from the deceased regarding their history, including criminal, and physical and mental health. While information on the quality of checks was not always available from the data, in some cases there was evidence that assessments were superficial, did not allow adequate answering by the deceased, or information was not communicated or acted upon adequately by the custody officers. This is similar to studies of deaths in custody in other countries, including the UK (IPCC, 2011), Germany (Heide, et al., 2009), and the Netherlands (Blaauw, et al., 1997). In those studies, most commonly, the detainee's level of intoxication was provided as the reason for the absence, or inadequacy, of a risk assessment, as well as overlooking injuries and underestimating the level of intoxication. In the UK, the IPCC (2011) states that “a detainee's unwillingness or inability to participate in a risk assessment should be viewed as a possible warning of risk" (p. 87).

The IPCC (2007) highlighted a trend of police failing to treat alcoholism with sufficient seriousness, which is mirrored in many of the cases in the present sample. Giles and Sandrin (1992) state that deaths from acute intoxication are among the most easily preventable deaths, as dangerous levels of blood alcohol concentration can be estimated/tested and medical attention provided. They note that police should be aware that tolerance in alcoholics may prevent the experience of some indictors of acute intoxication and, thus, some people may give the appearance of being less affected despite being in danger. This can also lead to complications around releasing detainees who appear to have sobered up but who may still be seriously affected by alcohol and vulnerable. 
The IPCC (2007) states that police custody staff should be trained (and refreshed) to recognise risk factors associated with alcoholism and that a history of alcohol abuse should be clearly recorded by admissions staff. Detainees should also be assessed for injury, particularly if police have witnessed an injury occur or there are visible signs of injury. Heide, et al. (2009) suggest that "persons with more than minor head injuries should, if in doubt, always receive CT or X-ray examination" (p. 600), but go on say that this will still not prevent all deaths. Indeed, the present sample included cases where the deceased had undergone assessment by trained medical personnel and was deemed fit for custody, but who subsequently died from their injuries.

Suicide risk assessment is also recommended practice during the admissions process, including recording any history of self-harm/suicide attempts or threats, as this has been shown to be a risk factor for suicide in police custody (Norfolk, 1998). Karch, et al. (1999) state that suicides are often preventable and that "custodial officers can be trained to recognize potential suicides and see to their wellbeing" (p.110). Norfolk (1998) reports that staff use of proformas in prisons have reduced suicide rates in those settings. However, preliminary work by the US Department of Justice (Gonzales, Henke \& Hart, 2007) has raised the need for culturally sensitive screening tools.

Monitoring. While assessment informs the likelihood of risk, communication of the risk and adequate measures to monitor and reduce risk must follow. Blaauw, et al. (1997) noted that "identifying detainees at risk of death...seems to have been less of a problem than knowing how to handle these detainees" (p.161). Staff shift changes require transfer of both risk assessment information and any instructions regarding care procedures. In the UK, the IPCC (2011) recommend that this is done in writing and also verbally, preferably in front of CCTV. 
In many cases of death in custody, inadequate monitoring of the deceased while in custody has been identified. Monitoring regularity and frequency differ across jurisdictions, and with the level of risk assessed. In the current sample, some cases did show evidence of regular checks, for example at 30 minute or 15 minute intervals. However, there were instances where death occurred within the first 15 minutes of custody. While CCTV in cells can reduce this risk, there were cases where CCTV was installed but not operational, or where custody staff were too busy to monitor the image. Heide, et al. (2009) suggested centralised custody facilities to ensure that those tasked with monitoring detainees in custody were not distracted by other duties. However, this may not be possible due to staffing and/or funding levels. In one Scottish district, Scottish Government Social Research (2009) reports the use of life monitoring equipment fitted in cells, incorporating "wave sensors...linked by radio to a computer...[to] monitor and measure various types of movement and noises" (p. 62).

While remote monitoring may be effective at alerting staff to some conditions or behaviour, cases where detainees suffer physical deterioration or loss of consciousness still require physical/verbal checks. Particularly, the importance of assessing consciousness has been noted by many. The current sample included cases where the deceased did not answer questions due to unconsciousness or semi-consciousness, and frequently were not physically roused during 'checks'. Heide, et al. (2009), the IPCC (2011), and Norfolk (1998) all stress the importance of assessing a person's consciousness and their ability to wake and provide a verbal response. Norfolk (1998) suggests the use of a tool to assess the level of consciousness, so that any changes can be monitored and responded to.

Environment. Suicides of Indigenous people in police custody were infrequent compared with other categories of death. All but one of the suicides within police custody 
occurred through hanging. Lyneham, Joudo Larsen, and Beacroft (2010) note that considerable improvements have been made to the safety of cell environments, including removing hanging points, and removing items from the detainees that could be used to inflict self-harm, for example potential ligatures. In the UK, the IPCC (2007) notes the provision of 'cut-down equipment' and medical resuscitation equipment.

\section{Concluding Remarks}

This paper adopted a stage framework of information gathering and processing for exploring officers' decisions and actions in encounters with Indigenous people that ended in death. This both highlights the utility of the framework, and aids understanding of cases of Indigenous deaths associated with police contact.

The study showed that, in many cases, officers received information at the initial stages that warranted a response of detention, with a variety of requests for service from the public concerning potential endangerment and offending. However, there were also many cases where the situations that police encountered could have resulted in less serious courses of action, with the provision of alternatives to arrest, pursuit or police custody. This may be particularly true for those cases that resulted in internal causes of death or vehicle-related deaths. Where cases warrant police detention, there is ample evidence from independent inquiries, Coronial examinations, and research and analysis, which highlights prevention efforts during the 'aftercare' stage, where a duty of care needs to be shown through adequate communication, assessment, monitoring and environmental considerations. While some advances are evident in recent years, a more systematic approach to improvement needs to encompass all stages of the incident, in order to best support and inform police decisionmaking when carrying out their duties. 
The author would like to acknowledge the Victorian Institute of Forensic Medicine for organising the National Coroners Information System database and approving access to that data for this research. Thanks are extended to the Australian Coroner Offices for provision of files and the Australian Institute of Criminology for liaising with those offices to assist the location of relevant cases. [Remainder removed for anonymous review] 
References

Australian Bureau of Statistics (2010). Causes of Death, Australia, 2010, accessed online $18^{\text {th }}$ July 2012 at http://www.abs.gov.au/ausstats/abs@.nsf/Products/FACE7C4E18F34496CA2579C600 $\underline{\text { OF7247?opendocument }}$

ACPO (2006). Guidance on the Safer Detention and Handling of Persons in Police Custody. London: The Association of Chief Police Officers.

ACPOS (2011). National Memorandum of Understanding between The Scottish Ambulance Service And Association of Chief Police Officers in Scotland (ACPOS): Management of People in the Community who are Drunk And Incapable, Version 1.0. Glasgow: Association of Chief Police Officers in Scotland. Accessed 6the January 2012 at http://www.acpos.police.uk/Documents/Policies/OPBA0037_MOU\%20ACPOS\%20an d\%20SAS $\% 20$ Management $\% 20$ of $\% 20$ People $\% 20$ in $\% 20$ the $\% 20$ Community $\% 20$ who\% 20are\%20Drunk\%20and\%20Incapble.pdf

Binder, A., \& Scharf, P. (1980). The violent police-citizen encounter. The ANNALS of the American Academy of Political and Social Science, 452(The police and violence), 111121.

Lyneham, M., Joudo Larsen, J., Beacroft, L. (2010). Deaths in custody in Australia: National Deaths in Custody Program 2008, Monitoring report no.10. Canberra: Australian Institute of Criminology.

Atkinson, J. (1994) A Nation is not Conquered, Domestic Violence \& Incest Resource Centre Newsletter, pp. 26-32.

Beresford, Q. \& Omaji, P. (1996) Rites of Passage: Aboriginal Youth, Crime and Justice. Fremantle Arts Centre Press, South Fremantle, W.A. 
Bittner, E. (1970). The functions of the police in modern society. Rockville, MD: National Institute of Mental Health.

Blaauw, E., Kerkhof, A. \& Vermunt, R. (1997). Suicides and Other Deaths in Police Custody. Suicide and Life-Threatening Behavior, 27(2): 153-163.

Dalton, V. (1998). Police Shootings 1990-97. Trends \& Issues in Crime and Criminal Justice, No.89. Australian Institute of Criminology: Canberra.

Fridell, L. A., \& Binder, A. (1992). Police officer decisionmaking in potentially violent situations. Journal of Criminal Justice, 20, 385-399.

Giles, H.G. \& Sandrin, S. (1992). Alcohol and Deaths in Police Custody. Alcoholism: Clinical and Experimental Research, 16(4): 670-672.

Gonzales, A.R., Henke, T.A., and Hart, S.V. (2007). American Indian Suicides in Jail: Can Risk Screening Be Culturally Sensitive? Washington: U.S. Department of Justice.

Heide, S., Kleiber, M., Hanke, S. \& Stiller, D. (2009). Deaths in German police custody. European Journal of Public Health, 19(6): 597-601.

Homel, R. Lincoln, R, \& Herd, B. (1999) Risk and Resilience: Crime and Violence Prevention in Aboriginal Communities. The Australian and New Zealand Journal of Criminology, 32(2): 182-196

Hunter, E., Reser, J., Baird, M. \& Reser, P. (2001). An Analysis of Suicide in Indigenous Communities of North Queensland: The Historical, Cultural and Symbolic Landscape. Canberra: Commonwealth of Australia.

IPCC (2007). Forum for Preventing Deaths in Custody Annual Report 2006-2007. London: Independent Police Complaints Commission.

IPCC (2011). Deaths in or following police custody: An examination of the cases 1998/99 2008/09. Research Series Paper: 17. London: Independent Police Complaints Commission. 
Joudo, J. \& Curnow, J. (2008). Deaths in custody in Australia: National Deaths in Custody Program annual report 2006. Canberra: AIC. Accessed 20/06/08 at http://www.aic.gov.au/publications/rpp/85/rpp85.pdf

Karch, S.B. \& Stephens, B.G. (1999). Drug abusers who die during arrest or in custody. Journal of the Royal Society of Medicine, 92:110-113.

Kesic, D., Thomas, S. D. M., \& Ogloff, J. R. P. (2010). Mental illness among police fatalities in Victoria 1982-2007: case linkage study. Australian and New Zealand Journal of Psychiatry, 44, 436-468.

Lawton, B. A. (2007). Levels of nonlethal force: An examination of individual, situational and contextual factors. Journal of Research in Crime and Delinquency, 44(2), 163-184.

Leigh, A. Johnson, G. and Ingram, A. (1998). Deaths in Police Custody: Learning the Lessons. Police Research Series Paper 26. London: Home Office.

Liebling, A. (1995). Vulnerability and prison suicide. British Journal of Criminology, 35(2): 173-187.

MacPherson, W. (1999). The Stephen Lawrence Inquiry. London: The Stationery Office Accessed $6^{\text {th }}$ January at http://www.archive.officialdocuments.co.uk/document/cm42/4262/4262.htm

McDonald, D., Howlett, C. \& Dalton, V. (1992). Deaths in Custody Australia: No. 1 Australian Deaths in Custody 1990 \& 1991. Canberra: Australian Institute of Criminology.

New Zealand Department of Corrections (2007). Over-representation of Māori in the criminal justice system: An exploratory report. Accessed $17^{\text {th }}$ January at http://www.corrections.govt.nz/_data/assets/pdf_file/0004/285286/Over$\underline{\text { representation-of-Maori-in-the-criminal-justice-system.pdf }}$ 
Norfolk, G. A. (1998). Deaths in police custody during 1994: a retrospective analysis. Journal of Clinical Forensic Medicine, 5: 49-54.

Pelfrey, W. V., \& Covington, M. W. (2007). Deaths in Custody: The Utility of Data Collected from County Coroners. Criminal Justice Studies, 20(1): 65 - 78.

Petschel, K., \& Gall, J. A. (2000). A profile of deaths in custody in Victoria, 1991-96. Journal of Clinical Forensic Medicine, 7(2): 82-87.

Queensland Coroner's Court (2006). Inquest into the death of Mulrunji. Townsville: Office of The State Coroner.

Scottish Government Social Research (2009). Managing the Needs of Drunk and Incapable People in Scotland: a Literature Review and Needs Assessment. Edinburgh: the Scottish Government. Accessed $6^{\text {th }}$ January 2012 at http://www.scotland.gov.uk/Publications/2009/10/29154403/8

Terrill, W., \& Mastrofski, S.D. (2002). Situational and officer-based determinants of police coercion. Justice Quarterly, 19(2), 2002.

The Royal Commission (1991). Royal commission into aboriginal deaths in custody (1991). Accessed 26/06/08 at http://www.austlii.edu.au/au/special/rsjproject/rsjlibrary/rciadic/

U.S. Department of Justice, Federal Bureau of Investigation. (2010, September). Crime in the United States, 2010: Persons arrested. Retrieved 17 $7^{\text {th }}$ January 2012 at http://www.fbi.gov/about-us/cjis/ucr/crime-in-the-u.s/2010/crime-in-the-u.s.2010/persons-arrested

Weber, L. (2007). Bridges or Bandaids?: Another Death in Police Custody Reveals Fatal Flaws in the Aboriginal Liaison Officer Concept. Current Issues in Criminal Justice, 19(2): 235-242. 
${ }^{1}$ Attempts were made to identify the missing cases through media searches in order to check for patterns. At least patchy information was found for eleven cases: Five operations related deaths (three identified as pursuit related, one unidentifiable cause of injuries, and one suicide by gunshot); four in custody deaths (three suicides, and one resist-arrest followed by death in transport); two natural causes during unidentified circumstances. No pattern was evident among these to suggest that missing cases constitute a subtype that would affect results. ${ }^{2}$ This was typically due to an undetermined cause of death, but for older files may also be due to a lack of information in the records obtained.

${ }^{3}$ This figure is slightly inflated by one case involving multiple deceased, but does not change the overall pattern.

${ }^{4}$ Nine cases were missing a more detailed determination. In one case another person caused the death: the deceased was a victim of domestic violence who police took into protective custody momentarily, due to intoxication. However, police left the scene without the deceased after a more serious call for service was heard over the radio. 
Table 1: Jurisdictional breakdown of number of sample cases and population statistics (source: Australian Bureau of Statistics, 2011).

\begin{tabular}{|c|c|c|c|c|c|c|}
\hline & $\begin{array}{c}\text { Number of } \\
\text { sample } \\
\text { cases }\end{array}$ & $\begin{array}{l}\text { Proportion of } \\
\text { sample cases }\end{array}$ & $\begin{array}{l}\text { Indigenous } \\
\text { population }\end{array}$ & $\begin{array}{c}\text { Proportion of } \\
\text { total } \\
\text { Australian } \\
\text { Indigenous } \\
\text { population }\end{array}$ & $\begin{array}{c}\text { Total Region } \\
\text { Population }\end{array}$ & $\begin{array}{l}\text { Indigenous } \\
\text { proportion of } \\
\text { total region } \\
\text { population }\end{array}$ \\
\hline Western Australia & 28 & 28.6 & 70,966 & 13.7 & $2,084,733$ & 3.40 \\
\hline Northern Territory & 27 & 27.6 & 64,005 & 12.4 & 212,335 & 30.14 \\
\hline New South Wales & 16 & 16.3 & 152,685 & 29.5 & $6,858,555$ & 2.23 \\
\hline Queensland & 12 & 12.2 & 144,885 & 28.0 & $4,139,685$ & 3.50 \\
\hline South Australia & 9 & 9.2 & 28,055 & 5.4 & $1,576,491$ & 1.78 \\
\hline Victoria & 4 & 4.1 & 33,517 & 6.5 & $5,170,618$ & 0.65 \\
\hline Tasmania. & 2 & 2.0 & 18,415 & 3.6 & 491,783 & 3.74 \\
\hline \multirow{2}{*}{$\begin{array}{l}\text { Australian Capital } \\
\text { Territory }\end{array}$} & 0 & 0 & 4282 & 0.8 & 337,077 & 1.27 \\
\hline & 98 & 100 & 516,810 & 100 & $20,871,277$ & \\
\hline
\end{tabular}


Table 2: Framework of incident stages for analysis, based upon Binder \& Scharf (1980) and Fridell \& Binder (1992)

\begin{tabular}{ll}
\hline Stage & Details relevant to officers' assessment \\
\hline Anticipation & $\begin{array}{l}\text { Information provided before contact, for example by dispatch } \\
\text { over the radio, by callers or witnesses etc. }\end{array}$ \\
Initial contact & $\begin{array}{l}\text { Direct information gathering, for example through observing the } \\
\text { deceased's behaviour and the situation }\end{array}$ \\
Information exchange & $\begin{array}{l}\text { Information conveyed by police and received from the deceased } \\
\text { Final decision }\end{array}$ \\
Aftercare & $\begin{array}{l}\text { pursue, use force etc. } \\
\text { All circumstances after detention, when the deceased is under the } \\
\text { care of police, including during transport and in custody. }\end{array}$ \\
\hline
\end{tabular}


Table 3: Selected characteristics of the deceased for the whole sample and also subsamples by cause of death.

\begin{tabular}{|c|c|c|c|c|c|c|}
\hline & $\begin{array}{c}\text { Whole } \\
\text { sample } \\
n=98\end{array}$ & $\begin{array}{c}\text { Internal } \\
\mathrm{n}=17\end{array}$ & $\begin{array}{c}\text { Vehicle } \\
n=39\end{array}$ & $\begin{array}{c}\text { Suicide } \\
n=18\end{array}$ & $\begin{array}{c}\text { Police } \\
n=8\end{array}$ & $\begin{array}{c}\text { Accident } \\
n=7\end{array}$ \\
\hline Male & $82 \%$ & $82 \%$ & $74 \%$ & $83 \%$ & $88 \%$ & $100 \%$ \\
\hline Mean Age & 29 & 40 & 23 & 31 & 28 & 28 \\
\hline Criminal history & $42 \%$ & $47 \%$ & $33 \%$ & $61 \%$ & $38 \%$ & $43 \%$ \\
\hline Drug/alcohol history & $37 \%$ & $65 \%$ & $13 \%$ & $61 \%$ & $38 \%$ & $43 \%$ \\
\hline $\begin{array}{l}\text { Under influence of } \\
\text { alcohol }\end{array}$ & $57 \%$ & $76 \%$ & $62 \%$ & $44 \%$ & $50 \%$ & $29 \%$ \\
\hline Under influence of drugs & $37 \%$ & $12 \%$ & $36 \%$ & $66 \%$ & $13 \%$ & $71 \%$ \\
\hline $\begin{array}{l}\text { Physical health problems } \\
\text { (history) }\end{array}$ & $21 \%$ & $71 \%$ & $3 \%$ & $22 \%$ & $12 \%$ & $14 \%$ \\
\hline $\begin{array}{l}\text { Mental health problems } \\
\text { (history) }\end{array}$ & $21 \%$ & $12 \%$ & $8 \%$ & $72 \%$ & $25 \%$ & $14 \%$ \\
\hline
\end{tabular}


Table 4: Cause of death and injury types.

What was the nature of injury?

Heart 12

What caused the injury?

Total

Internal Vehicle Suicide Police Accident

Other Missing person

Failure/disease

Stroke

2

Pneumonia

Pulmonary

embolism

Sudden

1

unexpected death

in epilepsy

Multiple injuries

Head injury

Gunshot

Hanging

Penetrating

wound

Drowning

Toxicity/overdose

Missing

1

1
26

11

$\begin{array}{ll}3 & 1 \\ 1 & 7\end{array}$

10

24
2

1

1

1
1

1

$1 \quad 29$

$1 \quad 16$

10

10

7

33

1

1

7

8

98
Total 
Table 5: Reason for initial police contact with the deceased.

\begin{tabular}{|c|c|c|c|c|c|c|}
\hline $\begin{array}{l}\text { What was the reason for } \\
\text { the initial contact? }\end{array}$ & $\begin{array}{c}\text { Internal } \\
\mathrm{N}=17\end{array}$ & $\begin{array}{l}\text { Vehicle } \\
\mathrm{N}=39\end{array}$ & $\begin{array}{c}\text { Suicide } \\
\mathrm{N}=18\end{array}$ & $\begin{array}{c}\text { Police } \\
\mathrm{N}=8\end{array}$ & $\begin{array}{l}\text { Accident } \\
\mathrm{N}=7\end{array}$ & Total \\
\hline Call for service & 8 & 6 & 10 & 7 & 4 & 35 \\
\hline Property & 1 & 2 & 0 & 3 & 2 & 8 \\
\hline Violence & 4 & 1 & 6 & 1 & 2 & 15 \\
\hline Armed & 1 & 0 & 2 & 4 & 0 & 7 \\
\hline $\begin{array}{l}\text { Fear harm to } \\
\text { others }\end{array}$ & 4 & 0 & 3 & 2 & 2 & 11 \\
\hline Fear harm to self & 0 & 0 & 2 & 0 & 1 & 3 \\
\hline Drunk & 4 & 0 & 2 & 0 & 1 & 7 \\
\hline Driving & 0 & 2 & 1 & 1 & 0 & 4 \\
\hline $\begin{array}{l}\text { Suspected/reported } \\
\text { criminal }\end{array}$ & 3 & 7 & 3 & 0 & 0 & 13 \\
\hline Driving behaviour & 0 & 10 & 0 & 0 & 1 & 11 \\
\hline Violent behaviour & 0 & 0 & 2 & 1 & 0 & 3 \\
\hline $\begin{array}{l}\text { Disorderly behaviour, } \\
\text { incl. Drunkenness }\end{array}$ & 4 & 1 & 1 & 0 & 0 & 6 \\
\hline Information & 0 & 1 & 1 & 0 & 1 & 3 \\
\hline Routine patrol/RBT & 1 & 9 & 0 & 0 & 0 & 10 \\
\hline Total & 16 & 34 & 17 & 8 & 6 & 81 \\
\hline
\end{tabular}


Table 6: Reason for attempt to detain.

\begin{tabular}{lcccccc}
\hline & $\begin{array}{c}\text { Whole } \\
\text { sample } \\
\mathrm{n}=98\end{array}$ & $\begin{array}{c}\text { Internal } \\
\mathrm{n}=17\end{array}$ & $\begin{array}{c}\text { Vehicle } \\
\mathrm{n}=39\end{array}$ & $\begin{array}{c}\text { Suicide } \\
\mathrm{n}=18\end{array}$ & $\begin{array}{c}\text { Police } \\
\mathrm{n}=8\end{array}$ & $\begin{array}{c}\text { Accident } \\
\mathrm{n}=7\end{array}$ \\
\hline $\begin{array}{l}\text { Reason for attempt to } \\
\text { detain*: }\end{array}$ & & & & & & \\
$\quad$ Minor (order, driving) & $42 \%$ & $41 \%$ & $62 \%$ & $17 \%$ & 0 & $29 \%$ \\
Theft or warrant & $21 \%$ & $18 \%$ & $31 \%$ & $17 \%$ & $25 \%$ & 0 \\
Own protection & $6 \%$ & 0 & 0 & $22 \%$ & $13 \%$ & $14 \%$ \\
$\quad$ Violence or siege & $22 \%$ & $35 \%$ & 0 & $33 \%$ & $63 \%$ & $18 \%$ \\
\hline
\end{tabular}

*some missing data means percentages do not all add up to $100 \%$ 
Table 7: Phase of death

\begin{tabular}{lccccc}
\hline Phase of Death & Internal & Vehicle & Suicide & Police & Accident \\
\hline Outside Custody & 2 & 36 & 7 & 8 & 5 \\
In transport & 4 & & 2 & & 1 \\
In cell & 3 & 1 & 7 & & \\
In Hospital & 7 & & & & \\
Post-release & 1 & 2 & & $0 \%$ & $14 \%$ \\
$\quad \begin{array}{l}\text { Death classified as*: } \\
\quad \text { Custody }\end{array}$ & $53 \%$ & $5 \%$ & $56 \%$ & $100 \%$ & $57 \%$ \\
$\quad$ Operations & $6 \%$ & $92 \%$ & $44 \%$ & & \\
\end{tabular}

*some missing data means percentages do not all add up to $100 \%$ 
Fig. 1: Number of cases sought based on AIC monitoring data, and actual number collected, by year of occurrence.

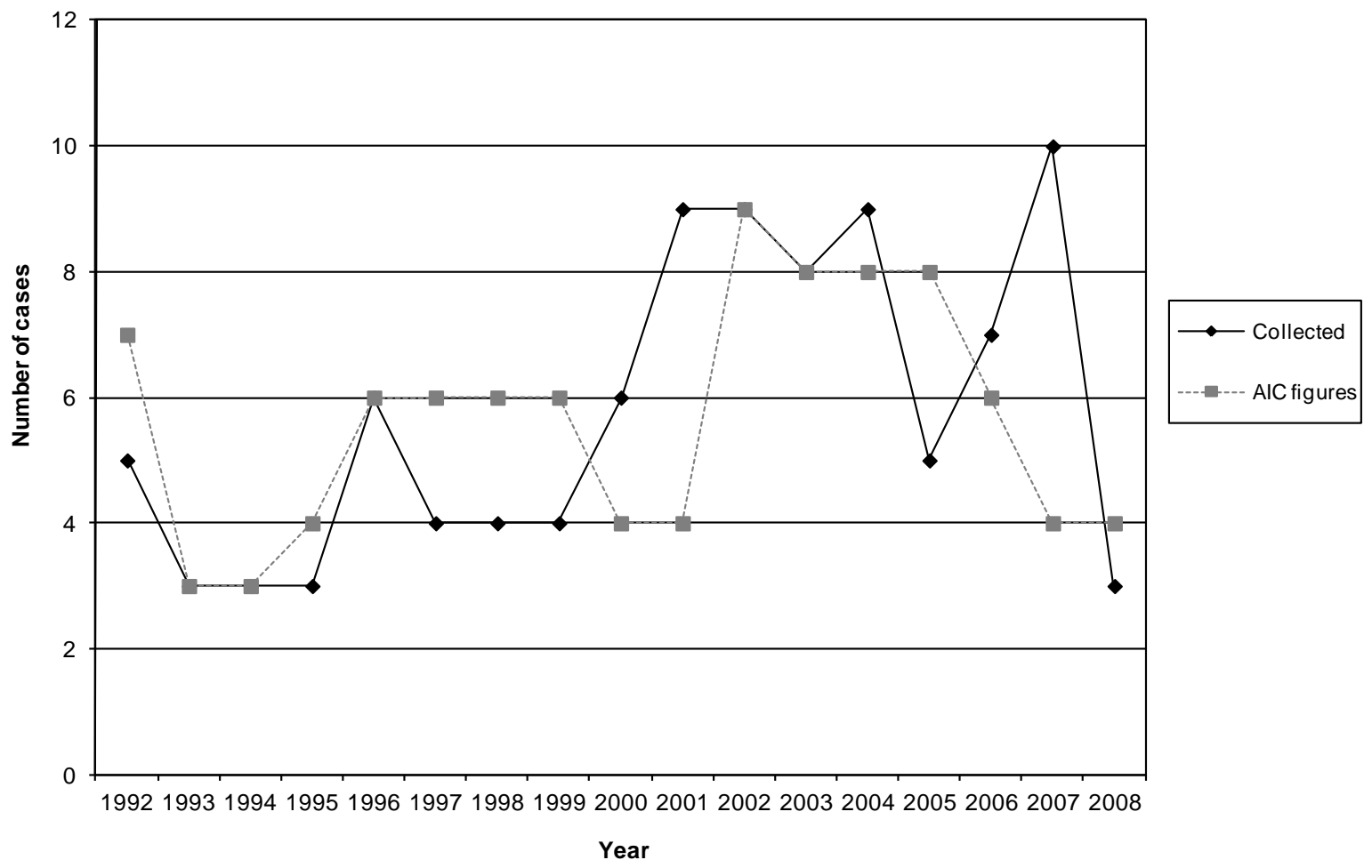


Fig 2: Cause of death by jurisdiction (State/Territroy)

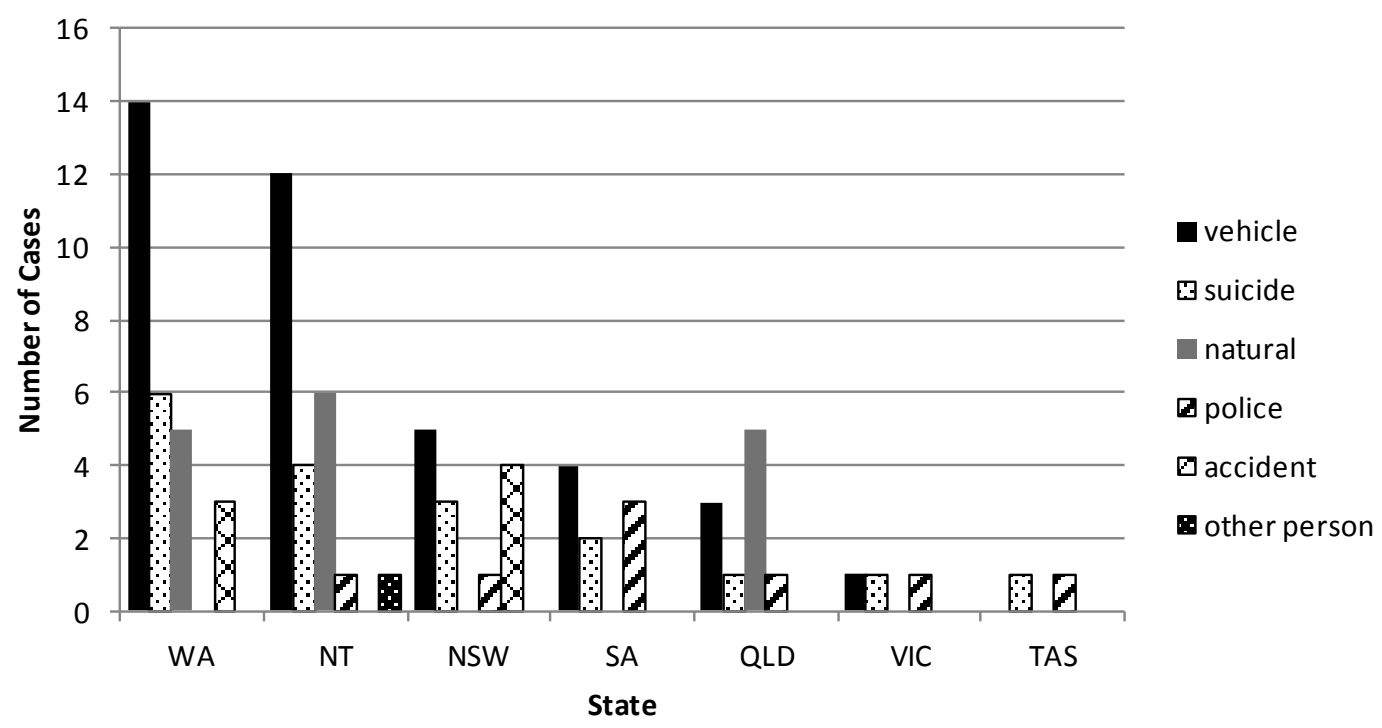

